\title{
Adverse effects of vancomycin in children: a review of 22 cases
}

\author{
Instituto da Criança do Hospital das Clínicas da Faculdade de Medicina da Universidade de São Paulo \\ Department of Pediatrics, University of São Paulo - São Paulo, Brazil
}

\begin{abstract}
Vancomycin has been frequently recommended for the treatment of multi-resistant infections. Twenty-two children undergoing vancomycin treatment were observed. Nine adverse effects were registered in 6 children: eosinophilia in 5 cases, skin rash in 2 cases, and an increase in plasma creatinine in 2 cases. All adverse effects remitted with withdrawal of the drug.
\end{abstract}

UNITERMS: Vancomycin. Adverse effects. Children. Antibiotics.

$\mathrm{V}$ ancomycin is a polypeptide antibiotic isolated in 1956 and introduced into medical practice in 1958 for treating infections caused by penicillinresistant staphylococci. ${ }^{1}$ It has many mechanisms of action, the best known and probably most important being the inhibition of cell wall synthesis in bacteria. $^{2}$ In addition to being extremely effective against Gram-positive bacteria, ${ }^{3-5}$ two features of vancomycin are of great interest in medical practice: the low level of bacterial resistance to the antibiotic, and the negligible incidence of cross reactions with other antibiotics.

Initial preparations of vancomycin contained many impurities frequently associated with adverse effects. Today, with drug purification, the number of patients who experience toxic effects is very small. Furthermore, wellcontrolled drug administration, according to technical

Address for correspondence:

Amélia Gorete A. C. Reis

Rua Alves Guimarães 623, apto 142, Jardim América

São Paulo/SP - Brasil - CEP 05410-001 standards, has also contributed to a reduction in the incidence of adverse effects.

After intravenous administration, vancomycin is distributed into various body fluids. Many factors influence the drug's pharmacodynamics, including age. Total body clearance of vancomycin increases with age. Due to the complex pharmacokinetics of the drug, the monitoring of the antibiotic concentration in plasma is recommended to assure successful therapy. ${ }^{6-9}$ are: ${ }^{10-12}$

The main adverse effects associated with vancomycin

- Histamine-like reaction, commonly seen as flushing and a maculo-papular rash of the face, neck, upper thorax, back and arms. The reaction may affect the entire body surface and be accompanied by itching, paresthesia, dizziness, fever, chest pain and edema of the face, lips, and eyelids. More severe symptoms such as tachycardia or bradycardia and, more rarely, systemic arterial hypotension or shock, may be observed $;^{13}$

- Nephrotoxicity has been associated with vancomycin since the beginning of its use. Analysis of these studies are difficult however, 
because many concomitant factors that may impair renal function in vancomycin treatment are also present in these studies; ${ }^{14.15}$

- Ototoxicity has been difficult to evaluate, as most patients are not submitted to audiometric tests during treatment. Impairment of the auditory nerve, considered the most severe adverse effect, may lead to permanent hearing loss; ${ }^{16,17}$

- Thrombophlebitis was frequent with initial preparations of vancomycin, occurring in up to 50 percent of cases. The incidence fell to between 6-13 percent after the purification process; ${ }^{18}$

- Today, fever and chills are rare adverse effects; they were more commonly observed with initial preparations of the antibiotic; ${ }^{10,19}$

- Hemotoxicity, mainly represented by neutropenia and eosinophilia, has been described more frequently, and does not seem to be related to dosage or plasma concentration of the drug. Blood count returns to normal values upon withdrawal of the drug; ${ }^{20}$

- Although increase in serum bilirubin has been associated to the use of vancomycin, there is no clear proof of hepatoxicity; ${ }^{10}$

Arterial hypertension has been described recently, although hypotension is the cardiovascular effect most frequently observed.

The Children's Institute of the Hospital das Clinicas of the University of São Paulo, a major tertiary hospital, treats children with chronic and/or severe diseases in which immunodepression, the use of invasive procedures, and frequent hospital admissions often lead to the development of multi-resistant Gram-positive bacterial infections. Vancomycin plays an important role in the treatment of these infections.

Therefore, we followed 22 children in whom vancomycin was clinically indicated for treating severe infections caused by suspected or confirmed multi-resistant staphylococci. We observed possible adverse effects of the drug through clinical and laboratory follow-up, and attempted to relate these effects to treatment length and plasma concentrations of the drug.
The drug was prepared for intravenous administration at a concentration of $5 \mathrm{mg} / \mathrm{ml}$. The dosage used was 15 $\mathrm{mg} / \mathrm{kg} /$ dose over a 60 -minute period, every 6 hours.

Measurements of plasma concentration of vancomycin were taken at maximal and minimal concentration levels of the phase of equilibrium, that is, after the second day of therapy. Plasma concentration was determined by polarized immunofluorescence on TDx equipment. As plasma concentrations presented great individual variation, levels of 30 to $40 \mathrm{mcg} / \mathrm{ml}$ at maximal, and below $10 \mathrm{mcg} / \mathrm{ml}$ at minimal were considered adequate. ${ }^{9}$ Optimum plasma levels were observed in only eight children.

Hemogram, urea and creatinine concentration, serum transaminase levels and urinanalysis were performed at the beginning of therapy and weekly during treatment in order to monitor adverse effects. Ototoxicity was not evaluated. Concomitant therapy with a cephalosporin or aminoglycoside was necessary in 14 cases.

Nine adverse effects observed in six children are described in the Table. Changes in plasma urea and creatinine levels upon introduction of vancomycin therapy did not occur.

The following adverse effects were observed: two cases of skin rash ( 9.1 percent), five episodes of eosinophilia (22.7 percent), and two cases of increase in serum creatinine concentration ( 9.1 percent).

Skin rashes were observed during drug infusion, and after the second week of treatment. Eosinophilia was defined as the number of eosinophils above 500 cells/ $\mathrm{ml}$, and was observed after the second week of treatment in five cases. Remission occurred after the end of treatment. Changes in plasma creatinine were observed during the second and third weeks of treatment. Twofold or greater increases were considered significant. Both cases with an increase in plasma creatinine concentration

Table

Adverse effects and serum concentrations of vancomycin

\begin{tabular}{|c|c|c|c|}
\hline & $\begin{array}{c}\text { Serum } \\
\text { concentrations } \\
\text { Peak }(\mathrm{mcg} / \mathrm{ml})\end{array}$ & $\begin{array}{c}\text { Serum } \\
\text { concentrations } \\
\text { Low }(\mathrm{mcg} / \mathrm{ml})\end{array}$ & $\begin{array}{l}\text { Adverse } \\
\text { Effects }\end{array}$ \\
\hline Case 1 & 50.4 & 25.6 & eosinophilia \\
\hline Case 2 & 37.7 & 16.7 & eosinophilia, skin rash \\
\hline Case 3 & 23.1 & 04.0 & $\begin{array}{l}\text { skin rash } \\
\text { increase in serum creatinine }\end{array}$ \\
\hline Case 4 & 30.9 & 08.1 & eosinophilia \\
\hline Case 5 & 54.6 & 15.0 & eosinophilia \\
\hline Case 6 & 29.9 & 05.6 & $\begin{array}{l}\text { eosinophilia } \\
\text { increase in serum creatinine }\end{array}$ \\
\hline
\end{tabular}


occurred with simultaneous use of other drugs, in one case amycacin, and in another, ceftriaxone. Creatinine plasma levels returned to normal after the drugs were withdrawn.

Serum concentrations above $40 \mathrm{mcg} / \mathrm{ml}$ occurred in two of the six children who suffered adverse effects, and in four children the serum concentrations were below 40 $\mathrm{mcg} / \mathrm{ml}$.

From the analysis of the data above we can conclude that:
- Plasma concentrations presented great individual variation, confirming that the recommended dosage of vancomycin is suitable for initial therapy, but serum concentrations should be monitored to adjust dosage;

- $\quad$ Significant adverse effects were not observed during infusion, suggesting that administration standards have a protective role;

- Adverse effects were transient and remitted after vancomycin was withdrawn.

\section{RESUMO}

Vancomicina é frequentemente recomendada para o tratamento de infecçöes causadas por Staphyloccus aureus multi-resistente. Foram observadas vinte e duas crianças recebendo tratamento com vancomicina. Foram registrados nove efeitos adversos em seis crianças: eosinofilia em cinco casos, exantema em dois casos e aumento da creatinina plasmática em dois casos. Todas as reações adversas regrediram com a retirada da droga.

\section{REFERENCES}

1. Geraci JE, Heilman FR, Nichols DR, Wellman WE, Ross GT. Some laboratory and clinical experiences with a new antibiotic, vancomycin. Proceedings of the Staff Meetings of the Mayo Clinic 1956;31:564-82.

2. Anderson JS, Matsuhashi M, Haskin MA, Strominger JL. Lipid-phosphoacetylmuramyl-pentapeptide and lipidphosphodisaccharide-pentapeptide: Presumed membrane transport intermediates in cell wall synthesis. Proc NAS 1965;53:881-9.

3. Wang WC, Wong WY, Rogers ZR, Wilimas JA, Buchanan GR, Powars DR. Antibiotic-resistant pneumococcal infection in children with sickle cell disease in the United States. J Pediatr Hematol Oncol 1996;18:140-4.
4. McGowan JE Jr, Metchock BG. Penicillin-resistant pneumococci: An emerging threat to successful therapy. J Hosp Infect 1995;30 Suppl:472-82.

5. Lee HJ, Park JY, Jang SH, Kim JH, Kim EC, Choi KW. High incidence of resistance to multiple antimicrobials in clinical isolates of Streptococcus pneumoniae from a university hospital in Korea. Clin Infect Dis 1995;20:826-35

6. Banner W Jr. Why read a pharmacokinetic article? AJDC 1986;140:104-6

7. Matzke GR, Zhanel GG, Guay DRP. Clinical pharmacokinetics of vancomycin. Clin. Pharmacokinet 1986;11:257-82.

8. Chang D. Influence of malignancy on the pharmacokinetics of vancomycin in infants and children. Pediatr Infect Dis J 1995; 14:667-73.

9. Logsdon BA, Lee KR, Barret FF. Correct dosing of vancomycin in infants and children. Pediatrics 1995;96:1177. 
10. Sorrell TC, Collignon PJ. A prospective study of adverse reactions associated with vancomycin therapy. J Antimicrob Chemother 1985;16:235-41.

11. Mellor JA, Kingdom J, Cafferkey M, Keane CT. Vancomycin toxicity: A prospective study. J Antimicrob Chemother 1985;15:773-80.

12. Woodley DW, Hall WH. The treatment of severe staphylococcal infections with vancomycin. Ann Internal Med 1961;55:235-49.

13. Odio C, Mohs, E, Sklar FH, Nelson JD, McCracken GH Jr. Adverse reactions to vancomycin used as prophylaxis for CSF shunt procedures. AJDC 1984;138:17-9.

14. Nahata MC, King DR, Powell DA, Marx SM, Ginn-Pease ME. Management of catheter-related infections in pediatric patients. JPEN J Parenter Enteral Nutr 1988;12:58-9.

15. Vance-Bryan K, Rotschafer JC, Gilliland SS, Rodvold KA, Fitzgerald CM, Guay DR. A comparative assessment of vancomycin-associated nephrotoxicity in the young versus the elderly hospitalized patient. J Antimicrob Chemother 1994;33:811-21.

16. Geraci JE, Heilman FR, Nichols DR, Wellman WE. Antibiotic therapy of bacterial endocarditis: VII vancomycin for acute micrococcal endocarditis. Proceedings of the Staff Meetings of the Mayo Clinic Nutr 1958;33:172-81.

17. Geraci JE, Hermans PE. Vancomycin. Mayo Clin Proc 1983;58:88-91.

18. Farber BF, Moellering RC Jr. Retrospective study of the toxicity of preparations of vancomycin from 1974 to 1981. Antimicrob Agents Chemother 1983;23:138-41.

19.Schaad UB, McCracken GH Jr, Nelson JD. Clinical pharmacology and efficacy of vancomycin in pediatric patients. J Pediatr 1980;96:119-26.

20. Shinohara YT, Colbert J. Vancomycin-induced neutropenia during treatment of endocarditis in a pediatric patient. Ann Pharmacother 1994;28:723-6. 